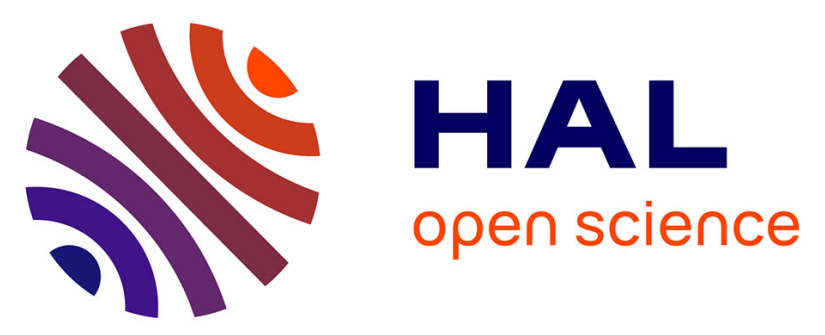

\title{
A review of the characteristics of the dinoflagellate parasite Ichthyodinium chabelardi and its potential effect on fin fish populations
}

Frank H Gleason, Maitreyi Nagarkar, Aurélie Chambouvet, Laure Guillou

\section{- To cite this version:}

Frank H Gleason, Maitreyi Nagarkar, Aurélie Chambouvet, Laure Guillou. A review of the characteristics of the dinoflagellate parasite Ichthyodinium chabelardi and its potential effect on fin fish populations. Marine and Freshwater Research, 2019, 70 (9), pp.1307-1316. 10.1071/MF18207 . hal02372310

\author{
HAL Id: hal-02372310 \\ https://hal.science/hal-02372310
}

Submitted on 20 Nov 2019

HAL is a multi-disciplinary open access archive for the deposit and dissemination of scientific research documents, whether they are published or not. The documents may come from teaching and research institutions in France or abroad, or from public or private research centers.
L'archive ouverte pluridisciplinaire HAL, est destinée au dépôt et à la diffusion de documents scientifiques de niveau recherche, publiés ou non, émanant des établissements d'enseignement et de recherche français ou étrangers, des laboratoires publics ou privés. 
1 A review of the characteristics of the dinoflagellate parasite Ichthyodinium

2 chabelardi and its potential effect on fin fish populations

3

4 Frank H Gleason ${ }^{1}$, Maitreyi Nagarkar ${ }^{2}$, Aurélie Chambouvet ${ }^{3}$, Laure Guillou $^{4}$

$6{ }^{1}$ School of Life and Environmental Sciences, University of Sydney, Sydney 2006,

$7 \quad$ Australia; frankjanet@ozemail.com.au

$8 \quad{ }^{2}$ Corresponding author; Marine Biology Research Division, Scripps Institution of

9 Oceanography, University of California San Diego, La Jolla, California, USA;

10 mnagarka@ucsd.edu

$11 \quad{ }^{3}$ Laboratoire des Sciences de l'Environnement Marin (LEMAR), UMR6539

12 UBO/CNRS/IRD/IFREMER, Institut Universitaire Européen de la Mer (IUEM),

13 Technopole Brest Iroise, 29280 Plouzané, France; aurelie.chambouvet@ univ-brest.fr

$14{ }^{4}$ Sorbonne Universités, Université Pierre et Marie Curie - Paris 6, CNRS, UMR 7144,

15 Station Biologique de Roscoff, Place Georges Teissier, CS90074, 29688 Roscoff cedex,

$16 \quad$ France; laure.guillou@ @b-roscoff.fr

17

18

19 Key words: Osteichthyes; Syndiniophyceae; Amyloodinium ocellatum; Saprolegnia

20 parasitica; Sphaerothecum destruens; X-cell species 
24 Abstract

26 This paper focuses on the biology and ecological impacts of Ichthyodinium chabelardi

27 (Phylum Dinophyta, Class Syndiniophyceae, Order Syndiniales), a virulent endobiotic

28 parasite of yolk sacs and young larvae of many species of marine fin fish. Its infections

29 have been observed in warm and temperate open oceanic environments and crowded

30 marine fish tanks. The prevalence of $I$. chabelardi and the range of its host fishes is not

31 well-studied, and our understanding of its life cycle is incomplete. Here we describe what

32 is known about I. chabelardi infections in fish and we compare this with several other

33 protistan parasites of fish, including Amyloodium ocellatum, Saprolegnia parasitica,

34 Sphaerothecum destruens, and the "X-cell" clades Gadixcellia and Xcellia, all of which

35 are considered emerging generalist parasites infecting a wide variety of fin fish species.

36 Recent findings suggest that rising seawater temperatures might lead to higher infection

37 rates in fishes, and we expect that these changing conditions could also expand the ranges

38 of some of these parasitic species. Thus, it is essential that the fishing industry effectively

39 monitor fish tanks and water in the surrounding environments for the presence of

40 zoosporic parasites including I. chabelardi in order to take steps to prevent large losses in

41 these fisheries.

42

43

44 


\section{Introduction}

\section{Objectives of this review}

47 This review focuses on the marine dinoflagellate parasite Ichthyodinium chabelardi

48 Hollande \& J. Cachon. The genus Ichthyodinium (Class Syndiniophyceae) consists of one 49 species, I. chabelardi. This species is a virulent, generalist, endobiotic parasite of embryos

50 and young larvae of many species of marine fin fish (Class Osteichthyes) living and

51 reproducing in the ichthyoplankton, primarily in tropical and warm temperate oceanic

52 ecosystems (Stratoudakis et al. 2000; Shadrin et al. 2010b). I. chabelardi has been

53 intensively studied in only a few host fin fish species. Most of the fin fish which carry this

54 parasite have been poorly investigated, even though some of the host fish species are

55 economically important food resources. Because there is some evidence that the

56 prevalence of other types of parasitic infections may increase with rising seawater

57 temperatures (van West 2006; Gozlan et al. 2014; Ercan et al. 2015), it is extremely

58 important to understand their mechanisms of infectivity, potential future distributions, and

59 begin to explore approaches to mitigation before they become an even greater threat to

60 fisheries.

61 Until now, no review of the literature on this parasite has been available. In contrast,

62 several compilations have been written about a closely related host generalist parasitic

63 protist belonging to the Hematodinium genus (also in the Class Syndiniophyceae)

64 (Stentiford and Shields 2005; Small and Pagenkopp 2011). The infectious agent of the

65 'bitter crab disease' (BCD) or the 'bitter crab syndrome' infects many commercially

66 important host species around the world including crabs, lobsters and amphipods. This

67 parasite has also been implicated in several outbreaks in fishery and aquaculture facilities

68 leading to substantial annual economic losses (Shields 1994; Stentiford and Shields 2005; 
69 Small et al. 2012). Given that $I$. chabelardi is also a generalist parasite infecting several

70 different species of fish hosts with high prevalence levels, we predict that it, too, could

71 have a significant impact on commercial fin fish populations.

72 In this review we firstly discuss the phylogeny, biology and ecology of I. chabelardi

73 focusing on its morphology and life cycle and the pathology of its infections in host

74 fishes. We then describe the putative geographical expansion and host shift of this

75 emerging disease and its potential ecological roles in marine food webs. We briefly

76 compare the biology of I. chabelardi with four other emerging zoosporic parasites which

77 commonly infect fin fish: Amyloodium ocellatum, Saprolegnia parasitica, Sphaerothecum

78 destruens and "X-cell" parasites. Finally, we appraise the future possibility of large losses

79 in production of marine fin fish to epidemics in fish farms unless measures are

80 implemented to prevent the spread of parasitic infections.

83 Baldauf $(2003,2008)$ divided all eukaryotic organisms into eight supergroups based upon consensus phylogeny. The supergroup Alveolata consists of a very diverse range of marine and freshwater protists belonging to three lineages: dinoflagellates, apicomplexans and ciliates. Presently the dinoflagellates (Phylum Dinozoa) include the following large

87 clades based on both molecular and morphological characteristics: Phylum Perkinsozoa

88 (Norén et al. 1999), Class Noctiluciphyceae (Gómez et al. 2010), Class Dinophyceae

89 (core dinoflagellates) (Pascher 1914), and Class Syndiniophyceae (to which

90 Ichthyodinium chabelardi belongs) (Loeblich III 1976). There are also several small

91 clades, one of which includes the genus Oxyrrhis (Lowe et al. 2010). 
92 Within the alveolates there are phototrophic, heterotrophic, and mixotrophic species. Most

93 of the core dinoflagellates are thought to be photosynthetic (including mixotrophs), but

94 there are also some heterotrophic species. Approximately half of all known dinoflagellate

95 species in all classes taken as a group are heterotrophic (Lessard and Swift 1986). Some

96 species of heterotrophic dinoflagellates contain plastids that lack a functional

97 photosynthetic apparatus (Robledo et al. 2011). The Phylum Perkinsozoa, Class

98 Syndiniophyceae, Class Blastodinophyceae, Class Noctiluciphyceae and the Oxyrrhis

99 clade are all groups of heterotrophic protists which lack functional chloroplasts and have

100 diverged into clades that are currently considered separate from the Class Dinophyceae

101 (core dinoflagellates) (Gómez et al. 2010; Bachvaroff et al. 2014).

102 I. chabelardi belongs to Class Syndiniophyceae which is composed of diverse lineages of 103 mainly endobiotic parasites, with several clades consisting entirely of uncultured species 104 (Moon-Van der Staay et al. 2001; Guillou et al. 2008). The Syndiniales are exclusive to 105 marine environments. Because of their endoparasitic lifestyle, they have unusual 106 adaptations, making them almost unrecognizable as dinoflagellates when inside their 107 hosts. The Syndiniales include at least five major marine alveolate (MALV) groups, 108 typically referred to as MALV I, II, III, IV, and V (but sometimes interchangeably as 109 Syndiniales I - V) (Guillou et al. 2008; Chambouvet et al. 2011). MALV II is currently 110 recognized as the most diverse clade and contains some of the more thoroughly studied 111 species, including numerous members of the genus Amoebophrya. Most members of 112 MALV II have been identified as parasites of dinoflagellates, although some also infect 113 radiolarians. Members of MALV IV infect other metazoans including Hematodinium, and 114 Syndinium, two well-characterized parasites of crustaceans. MALV III and MALV V 115 currently consist entirely of environmental sequences, but form well-supported clades 
116 (Guillou et al. 2008). Finally, MALV I includes Ichthyodinium spp. as well as members

117 that infect ciliates (Euduboscquellidae) (Coats 1988; Coats and Heisler 1989; Harada et

118 al. 2007; Jung et al. 2016). A schematic representation of the position of MALV I relative

119 to other members of Syndiniales and Dinophyceae is provided in Figure 1A.

120 Ichthyodinium chabelardi was originally described as a syndinid dinoflagellate by

121 Hollande and Cachon (1952) with additional observations on its morphology and biology

122 (Hollande and Cachon, 1953). Morphologically, I. chabelardi shares key features with

123 other dinoflagellates. These include trichocysts, condensed chromatin in the nucleus of

124 trophic stages, a dinospore (or zoospore) with two lateral flagella, and an alveolate pellicle

125 synthesized inside alveolar membranes (Hollande and Cachon 1952; Gestal et al. 2006;

126 Simdyanov et al. 2016).

127

128 The phylogenetic placement of I. chabelardi within the Alveolata superphylum remains

129 controversial. Gestal et al. in 2006 using molecular methods placed this parasite at the

130 base of the Perkinsozoa lineage, renaming the genus Perkinsoide (Gestal et al. 2006).

131 However, analysis of the SSU and LSU regions show poor support for this change, and

132 zoospore ultrastructure is more similar to other groups of dinoflagellates than the

133 Perkinsozoa. As with recent authors (Mori et al. 2007; Skovgaard et al. 2009; Simdyanov

134 et al. 2016), we retain the placement of I. chabelardi in the Syndiniophyceae until

135 additional work is done on its taxonomic affinities.

136 Although only one species has been formally described thus far, genetic analysis of the

137 SSU rDNA of the parasitic protists infecting a mix fish larvae of eight different species

138 reveal slight differences in the sequences, which suggests that there could be at least two

139 different ribotypes (98\% of identity - $22 \mathrm{nt} / 868 \mathrm{bp}$ ) in the sample (Sørensen et al. 2014). 
140 These form separate clades within MALV I - 3 when aligned with other environmental

141 SSU rDNA sequences (Figure 1B). These two ribotypes have been detected to date in

142 distinct oceanic regions (Figure 2). These results provide the evidence that this group

143 might be more complex than previously described and composed of genetically distinct

144 parasites, as has been characterized for other syndinean parasites such as Amoebophrya

145 spp. (Guillou et al. 2008).

\section{$148 \quad$ Life cycle of $I$. chabelardi}

149 Ichthyodinium chabelardi was originally described as an infectious agent of sardines from 150 the Mediterranean Sea (Alger Bay) by Hollande and Cachon (1952), who made additional 151 observations on its morphology and biology (Hollande and Cachon 1953). These

152 descriptions reveal a complex life cycle that might differ depending on the parasite and/or 153 host species, with infections in some hosts appearing to have two generations of schizonts 154 while others have been observed with three (Figure 3). Subsequently, free-swimming 155 zoospores are released which can then infect new hosts.

156 The first evidence of infection appears in the yolk sac of embryos after gastrulation 157 (stages VI to XI, Dulčić 1998; Meneses et al. 2003). Infected eggs have no sign of 158 penetration on their surface, suggesting that the parasite may pass through the hole for 159 sperm penetration before the hole is completely closed (Yuasa et al. 2007).

160 Three successive stages of schizonts have been described by Hollande and Cachon (1953):

161 Primordial schizonts: The smallest stages of the parasite appear to be unicellular spheres 162 (maximum 1 to 3 per egg) with a diameter of approximately $8-15 \mu \mathrm{m}$, less than $20 \mu \mathrm{m}$ 
163 (Hollande and Cachon 1952, 1953; Meneses et al. 2003; Yuasa et al. 2007; Sorensen et al.

164 2014). These trophocytes absorb the vitellus material of the host in a central vacuole and

165 remain uni-nucleated, although mitotic divisions following by transversal divisions may

166 occur at this stage. Then, the nucleus undergoes multiple mitotic divisions without

167 subsequent cytoplasmic division and the primordial schizont rapidly becomes a large

168 multinucleated structure of 100-140 $\mu \mathrm{m}$. The cytoplasm forms cylindrical projections

169 around each nucleus and each of these units become a secondary schizont $(\sim 20-30 \mu \mathrm{m})$

170 that eventually separates from the rest in a budlike manner.

171 Secondary schizonts: These are cylindrical or in a racket-like shape, about $20 \mu \mathrm{m}$ in

172 length (Hollande and Cachon 1953). Lecithin starts to concentrate in these forms. This

173 early secondary schizont first grows, then begins to divide by longitudinal bipartitions. As

174 the posterior poles of the two daughter cells remain attached, the parasites assume a

175 triangular form, resembling to a 'rosace'. Secondary schizonts can then form a long cord

176 (up to 1-2 mm) in layers of successive groups of eight cells connected by their poles

177 (Hollande and Cachon 1953).

178 Last generation of schizonts: Oblong (cylindrical) schizonts are released from the cord,

179 which become spherical after a series of divisions. At this phase, the yolk sac is opaque

180 and entirely occupied by uni-nucleated parasitic cells. This last generation of schizonts

181 produce zoosporangia, which are released outside the host, in the water, generally after

182 hatching. The yolk sac breaks causing the death of the newly hatched larvae. In some

183 larvae, the parasite burst occurs immediately after hatching, while it takes more than $10 \mathrm{~h}$

184 after hatching in others (Mori et al. 2007). The number of sporangia released from a yolk-

185 sac larva of the yellowfin tuna Thunnus albacares has been estimated to be about $4 \times 10^{4}$

186 cells (Yuasa et al. 2007). 
In the water, the sporangia undergo one to two divisions and become flagellated (Hollande and Cachon 1953). These spores have trichocysts (Gestal et al. 2006), which are known to be involved in the host attachment in other Syndiniales (Miller et al. 2012). Nuclei of released spores exhibit numerous nuclear pores and have chromatin masses, permanently condensed in circular or oval profiles of DNA. In some cases, structures like rhoptries and microtubule-organizing centres, similar to specific apicomplexan characteristics, have been observed at this developmental phase (Gestal et al. 2006). These structures may have similar function during the host invasion as the dense bodies and striated strips observed in Amoebophrya (Miller et al. 2012). Spores remain actively swimming for a few days, but cannot survive in a free-living state beyond that (Hollande and Cachon 1953). Spores of different sizes (Skovgaard et al. 2009) seem to correspond to different generations of division (Shadrin et al. 2015). The fate of the parasite outside of the host is not known at present.

Variations observed from this complex life cycle: The three generations of schizonts, first described on sardines from the Mediterranean Sea, were also observed in the mackerel off Portugal (Meneses et al. 2003). However, secondary schizonts seem to be absent on sardines from Portugal (Borges et al. 1996; Gestal et al. 2006) and several other host species, such as Plectropomus leopardus from Japan (Mori et al. 2007) and Thunnus albacore (Yuasa et al. 2007). In this case, primary schizonts lead directly to the last generation schizonts, without producing the rosace and cord. No zoosporangium was formed in Plectropomus leopardus from Japan (Mori et al. 2007); instead, schizonts themselves transformed into zoospores within 10 minutes after release. 
211 Parasitic species appear to be highly ubiquitous in the world's oceans. Known parasites

212 comprised more than half of both the richness and abundance of sequences within the

213 pico-nanoplankton size fraction collected in the TARA Oceans expedition, which sampled

214 at 68 stations across the world's oceans (de Vargas et al. 2015). Within the TARA study,

215 the Syndiniales featured prominently and over 2000 species-level OTUs were assigned to

216 the MALV I clade (which includes Ichthyodinium spp.). Additionally, parasitic

217 interactions were the most common type of interaction identified from network analysis of

218 this global sequence dataset (Lima-Mendez et al. 2015).

219 There is evidence that parasitism by certain Syndiniales species could play a role in

220 regulating the populations of their hosts. This has even been suggested as a means of

221 controlling harmful algal blooms since many toxic dinoflagellates have been identified as

222 Syndiniales hosts (Taylor 1968). In the Penzé estuary in France, Chambouvet et al. (2008)

223 consistently found successive blooms and declines of four different dinoflagellate species,

224 with prevalence of different Syndiniales species corresponding to or shortly lagging each

225 of the four dinoflagellate blooms. It is clear that in certain cases Syndiniales species can

226 heavily impact the dynamics of their host populations, and given the incredible diversity

227 of hosts, their regulatory effects on a wide range of marine organisms, including fishes,

228 are understudied.

229 Microscopic and molecular analysis of pelagic samples of ichthyoplankton have revealed

230 the presence of $I$. chabelardi and relatives in the yolk sacs of fertilized eggs, embryos and

231 larvae in various species of fish at widely distributed sites in the South China Sea (Shadrin

232 et al. 2010 a and b), South Pacific (Yuasa et al. 2007) and in the North Eastern Atlantic

233 and the Mediterranean (Dulčic 1998; Skovgaard et al. 2009). Up to now, I. chabelardi is

234 reported to infect at least 13 different marine fish species including several commercially 
235 important species such as Maurolicus muelleri (Guelin) and Sparus aurata L., Trachurus

236 trachurus L., Micromeesistius poutassou (Risso) and Engraulis encrasicolus L. and

237 Scophthalmus morhua L. (see Table 1 for more details on observations in certain host

238 species, Figure 2 for geographical distribution, and the Aquasymbio website:

239 http://www.aquasymbio.fr/fr).

240 The presence of this pathogen has not been reported elsewhere in the ocean in wild host

241 fish species but has become a pest in some fish farms (Mori et al. 2007; Yuasa et al.

242 2007). No data has been collected for the prevalence of $I$. chabelardi at most other sites at

243 which general surveys for dinoflagellates have been conducted. Most sampling sites

244 where I. chabelardi has been detected have been in warm water. The only surveys in cold

245 water were near Denmark (Sørensen et al. 2014). It is therefore clear that I. chabelardi

246 and relatives are generalist parasites infecting many bony fish species and are widely

247 distributed throughout the oceans. However, most of the studies thus far focus on few

248 ecosystems and broader surveys are required today to establish the global distribution of 249 theses parasites.

251 Infectivity and ecological significance

252 The prevalence of Ichthyodinium parasites in ichthyoplankton samples has been

253 investigated in various euphotic zones (North Atlantic, Mediterranean, South China and

254 South Pacific waters). These shorter-term studies highlight a surprisingly high prevalence

255 (Pedersen et al. 1994; Stratoudakis et al. 2000; Skovgaard et al. 2009). For example, field

256 studies in the North Atlantic revealed infection prevalences of $37 \%$ in sardine eggs in

2571999 and 46\% in mackerel eggs in 2000 (Stratoudakis et al. 2000; Meneses et al. 2003). 
258 In the South Pacific the prevalence was nearly 100\% for yellow fin tuna in 2007 (Yuasa et 259 al. 2007).

260 More recently, Shadrin et al. (2010b) confirm this high prevalence at Nha Trang Bay,

261 Vietnam between 2001 and 2010 detecting Ichthyodinium-like parasite in representatives 262 of eight families of fish. These long-term observations reveal also an increase of parasitic 263 prevalence year after year leading to a substantial proportion of fish mortality at early 264 developmental stages. Hence, infection prevalence was no more than $1 \%$ in 1993, but 265 reached up to $98 \%$ in 2006 . Similarly, a recent study on the leopard coral grouper fish in 266 southern Japan reveal that parasitic prevalence attributed to Ichthyodinium sp. ranged in 267 the same batch from $1.9 \%$ in 1990 to $31.8 \%$ in 1995 (Mori et al. 2007).

268 Shadrin et al. (2010a) have suggested that infection by $I$. chabelardi has been responsible 269 for the significant disappearance of populations of fish species in warm water off the coast 270 of Vietnam. The quantitative effect of infection by this parasite elsewhere awaits further 271 long-term investigation. However, present data suggest that I. chabelardi is an emerging 272 pathogen and is spreading into new marine ecosystems and possibly into freshwater 273 ecosystems (Sørensen et al. 2014).

274 Taken all together, these findings data suggest that the impact of this parasite on fish host 275 populations is still today underestimated and long-term investigation is urgently needed.

\section{Other emerging eukaryotic parasites of fish}

278 Ichthyodinium chabelardi is not alone in its role as an emerging threat to fisheries. Several 279 other protists of differing phylogenetic origins, and different life cycles and modes of 
infection, also present a challenge for fishery management. Here we briefly describe the mechanisms and effects of five other eukaryotic parasites.

Amyloodium ocellatum (Class Dinophyceae, Order Peridiniales) is known to infect over 100 species of fin fish worldwide causing marine velvet disease or amyloodiniosis

284 (Landsberg et al. 1994, see also the Aquasymbio website: http://www.aquasymbio.fr/fr).

285 A. ocellatum is a virulent euryhaline ectobiotic parasite that tolerates varying osmotic 286 conditions and temperatures and is commonly observed in warm and temperate oceanic 287 environments including coral reefs and especially in crowded fish pens and aquaria (Noga 1989; Levy et al. 2007). This species can grow at temperatures of up to $40^{\circ} \mathrm{C}$ (Kuperman and Matey 1999). The details of its life cycle have been worked out, and there do appear

290 to be seasonal, temperature-related dynamics of infection prevalence (Kuperman and 291 Matey 1999). Its free-swimming dinospore stage attaches to the gills and skin of hatched 292 fish (Kuperman and Matey 1999) rather than the eggs as does I. chabelardi.

293 Saprolegnia parasitica (Phylum Oomycota) and Sphaerothecum destruens (Phylum

294 Mesomycetozoa) are known to be significant emerging parasites and are very serious 295 threats for production in populations of both wild and farmed fin fish in freshwater 296 ecosystems (van West 2006; Rowley et al. 2013; Gozlan et al. 2014; Sarowar et al. 2014). 297 Both species have been spread widely by resistant carriers into new ecosystems where 298 these pathogens have formerly never been observed.

299 Several pathotypes of Saprolegnia can act as opportunistic and aggressive parasites of 300 egg, larval and adult stages of many economically important species of fish such as 301 salmon, trout and catfish, and are responsible for significant economic losses in salmon 302 hatcheries. Thoen et al. (2015) found many different ITS-based genotypes among 89 
303 isolates of Saprolegnia recovered from water samples and egg, larval and adult salmon

304 tissues from 26 salmon hatcheries along the coast of Norway. A limited number of species

305 of Saprolegnia (four species) were found in tissues of salmon: diclina, ferax, hypogyra

306 and parasitica. S. diclina (sub-clade IIIB) clearly dominated and accounted for $79 \%$ of the

307 recovered species. These data indicate considerable genetic variation within the

308 populations of Saprolegnia pathogens, but the relationship to pathogenicity is not known.

309 Sphaerothecum destruens was spread from China to Europe by a healthy freshwater

310 carrier species, the top-mouth gudgeon (Pseudorasbora parva) (Gozlan, 2014). Recently

311 the rate of spread within parts of Europe has been estimated to be very rapid (Ercan et al.

312 2015). This pathogen is a generalist, can infect a wide range of hosts and can cause high

313 mortalities, especially in commercially important fish species such as Chinook salmon

314 (Oncorhynchus tshawytscha) and Atlantic salmon (Salmo salar).

315 The "X-cell" clades Gadixcellia and Xcellia (Superphylum Alveolata) are parasites

316 associated with tumor-like formations in teleost fishes, including several groups of

317 commercial interest (Freeman et al. 2017). X-cells were originally believed to be

318 abnormal, diseased host cells, but cells extracted from lesions in the gills and skin of

319 various fishes reveal them to be a related group of parasitic protists. The phylogeny of

320 these parasites is newly characterized and shows an unexpected level of divergence

321 between the two robust x-cell clades within the Phylum Perkinsozoa (Alveolata). Both

322 clades are basal to the Perkinsids. Fishes with $\mathrm{x}$-cell infections have been observed in the

323 Atlantic, Pacific, and Southern oceans (Evans and Tupmongkol 2014; Freeman et al.

324 2017), but the parasites have not yet been observed, nor their sequences detected, in

325 seawater independently of their hosts. In the common dab, diseased fish had difficulty

326 with respiration and much lower survival than healthy fish (Diamant and Vicar 1987). 
327 It is clear that Ichthyodinium chabelardi is not the only infectious disease threatening the

328 future survival of important fisheries. Many diseases have been described. Moreover,

329 eukaryotic parasites have been under-studied and neglected so far despite their major role

330 in fish disease. Some methods have been proposed to control the spread of these parasites

331 in controlled environments including reduced salt concentration and various chemicals,

332 though some of these (like malachite green) have been banned due to their toxicity to

333 humans (van West 2006). Further knowledge of each of these parasites, especially their

334 early detection and predicted responses to changing ocean conditions, will be of crucial

335 importance to the future of fish production.

337 Future perspectives and conclusions

338 There are plans in the future to build new hatcheries for production of marine fin fish

339 species such as cod along the coasts where appropriate. Countries such as Norway,

340 Scotland, Canada and southern Australia currently have only salmon hatcheries filled with

341 cold freshwater. These facilities could be easily modified for marine fish using cold

342 seawater. However, a dramatic increase of disease caused by Saprolegnia in freshwater

343 fish tanks has already been observed (van West 2006). This appears to be a result of two

344 factors: the mean temperature of the ocean is predicted to increase significantly with

345 global warming, and furthermore the use of malachite green in the tanks to prevent the

346 growth of parasites has been banned internationally because of its toxicity to humans (van

347 West 2006).

348 It is often concluded that geographical range and prevalence of emerging infectious

349 diseases has increased tremendously over the last 20 years (Harvell 1999, 2002; Sutherst 
350 2001). Climate change, habitat destruction, and introduction of exotic species (hosts and 351 parasites) have been blamed for this increase. Actually, it has recently been observed that

352 the combination of introduction of diseased fish with the rise of seawater temperature has

353 significantly increased the prevalence of diseases of fin fish in general (van West 2006;

354 Gozlan 2014; Ercan et al. 2015). We therefore predict that the ocean temperature increase

355 will provide more favourable environmental conditions for parasite growth and will

356 inexorably lead to geographical expansion of infectious agent populations like $I$.

357 chabelardi and other protozoan parasites. This movement could impact population

358 dynamics and may drive a decrease of or even cause extinction of commercially important

359 fish population stock. It is not known whether fish could have a designated area to provide

360 protection from infection by this parasite, but cold water in the oceans near the poles

361 could be a reservoir if there is sufficient oxygen present.

362 It is essential that the fishing industry effectively monitor fish tanks and water in the

363 surrounding environments for the presence of parasites and takes steps to prevent large

364 losses in fish production. At present efforts to measure the prevalence of these parasites 365 appear to be inadequate. Molecular methods may provide tools for early detection (for 366 example, PCR of environmental samples using Ichthyodinium-specific primers), but

367 further research is required to develop new procedures for monitoring and controlling 368 infections. Mori et al. (2007) were able to prevent horizontal transfer of infection by using

369 UV-sterilized or ozone-treated seawater. Methods such as these might warrant further 370 exploration for fish tank settings.

371 Pathogenic species such as I. chabelardi and the others discussed in this paper infect a 372 wide variety of host species that may favor their spread. Generalist parasites have been 373 responsible for huge losses in populations of plants and animals in agriculture, 
374 aquaculture and the environment (Phillips et al. 2008). All of the species discussed in this 375 review are examples of emerging pathogens and equally important to the economy of the 376 aquaculture industry (Stentiford et al. 2012) in a world in which food production must be

377 increased to keep up with human population growth. They are all spread easily and 378 rapidly by highly infective free-living stage the zoospores from infected to uninfected 379 susceptible host species of fish and could cause epidemics especially in highly dense host 380 populations such as in fish farms.

Figure Legends

384 Figure 1. (A) Generalized schematic of Dinophyceae phylogeny with designation of the 385 five major clades within Syndiniales. MALV I, to which Ichthyodinium spp. belong, is 386 highlighted. Adapted from Guillou et al. 2008. (B) Partial SSU rDNA phylogeny 387 (Maximum Likelihood) of Ichthyodinium spp. together with closely related environmental 388 sequences (MALV I clade 3, following the nomenclature by Guillou et al. 2008), showing 389 the two clusters described within the genus. Environmental sequences are labeled by their 390 GenBank accession number following by the name of the clone. Sequences were retrieved 391 from GenBank using BLAST and aligned with referenced Ichthyodinium spp. sequences 392 using the online version of MAFFT version 7 (https://mafft.cbrc.jp/alignment/server/), and 393 considering the secondary structure of RNA. RAxML (Randomized Axelerated Maximum 394 Likelihood) was performed using the GTRCAT substitution model, using a random 395 number seeds, and 100 replicates for the bootstrap analyses. 
397 Figure 2. Known global distributions and hosts of the two established ribotypes of 398 Ichthyodinium sp.

400 Figure 3. Life cycle of $I$. chabelardi as observed in mackerel eggs (from Meneses et al. 401 2003).

402

403 Table 1. Some examples of pathotypes of Ichthyodinium chabelardi reported as parasites 404 of fish species. Recently identities have been confirmed by both light microscopic studies 405 and molecular methods.

406 
408 The authors thank Jeffrey D. Shields, Virginia Institute of Marine Science, Gloucester 409 Point, VA 23062, for his provision of references, advice, and encouragement during this 410 project and Natalie M. Mikac, University of Sydney for her assistance preparing the 411 manuscript. AC was supported by the project PARASED ANR-16-ACHN-0003. LG was 412 supported by the ANR HAPAR 14-CE02-0007. MN was supported by the NSF GRFP 413 (DGE-1144086).

414

415 Conflict of Interest

416 The authors declare no conflict of interest. 
418 Bachvaroff, T. R., S. G. Gornik, G. T. Concepcion, R. F. Waller, G. S. Mendez, J. C.

419 Lippmeier, and Delwiche, C. F. (2014). Dinoflagellate phylogeny revisited: using 420 ribosomal proteins to resolve deep branching dinoflagellate clades. Molecular $421 \quad$ Phylogenetics and Evolution 70, 314-322.

423 Baldauf, S. L. (2003). The deep route of Eukaryotes. Science 300, 1703-1706.

Baldauf, S. L. (2008). An overview of the phylogeny and diversity of eukaryotes. Journal of Systematics and Evolution 46, 263-273.

Borges, R., Ré, P. and Azevedo, C. (1996). Ichthyodinium chabelardi (Hollande e Cachon 429 1952), dinoflagelado parasita dos ovos de sardinha. Ciência Biologica. Ecology and Systematics (Portugal) 16, 245-258. dinoflagellate blooms by serial parasitic killers. Science 322(5905), 1254-1257.

Chambouvet, A., Alves-de-Souza, C., Cueff, V., Marie, D., Karpov, S., and Guillou, L. (2011). Interplay between the parasite Amoebophrya sp. (Alveolata) and the cyst formation of the red tide dinoflagellate Scrippsiella trochoidea. Protist 162(4), 637-649. 
439 Coats, D. W. (1988). Duboscquella cachoni n. sp., a parasitic dinoflagellate lethal to its

440 tintinnine host Eutintinnus pectinis. The Journal of Protozoology 35(4), 607-617.

442 Coats, D. W., and Heisler, J. J. (1989). Spatial and temporal occurrence of the parasitic

443 dinoflagellate Duboscquella cachoni and its tintinnine host Eutintinnus pectinis in

444 Chesapeake Bay. Marine Biology 101(3), 401-409..

446 De Vargas, C., Audic, S., Henry, N., Decelle, J., Mahé, F., Logares, R., Lara, E., Berney,

447 C., Le Bescot, N., Probert, I. and Carmichael, M. (2015). Eukaryotic plankton diversity in 448 the sunlit ocean. Science 348(6237), 1261605.

Diamant, A., and McVicar, A. H. (1987). The effect of internal and external X-cell lesions on common dab, Limanda limanda L. Aquaculture 67(1-2), 127-133.

Dulčić, J. (1998). Infection of sardine eggs by a parasitic dinoflagellate Ichthyodinium

454 chabelardi Hollande and Cachon, 1952 in Croatian waters. Annales: anali za istrske in 455 mediteranske študije. Series historia naturalis 13, 15-18.

457 Ercan, D., Andreou, D., Sana, S., Öntaş, C., Baba, E., Top, N., Karakuş, U., Tarkan, A.S. 458 and Gozlan, R.E. (2015). Evidence of threat to European economy and biodiversity 
459 following the introduction of an alien pathogen on the fungal-animal boundary. Emerging 460 microbes \& infections $\mathbf{4}(\mathbf{9}), 52$.

461

462 Evans, C. W., and Tupmongkol, K. (2014). X-cell disease in Antarctic fishes. Polar 463 biology 37(9), 1261-1269.

464

465 Freeman, M.A., Fuss, J., Kristmundsson, A., Bjorbækmo, M.F., Mangot, J.F., del Campo, 466 J., Keeling, P.J., Shalchian-Tabrizi, K. and Bass, D. (2017). X-Cells Are Globally

467 Distributed, Genetically Divergent Fish Parasites Related to Perkinsids and 468 Dinoflagellates. Current Biology, 27(11), 1645-1651.

469

470 Gestal, C., Novoa, B., Posada, D., Figueras, A., and Azevedo, C. (2006). Perkinsoide

471 chabelardi n. gen., a protozoan parasite with an intermediate evolutionary position:

472 possible cause of the decrease of sardine fisheries?. Environmental microbiology $8(\mathbf{6})$, $473 \quad 1105-1114$.

474

475 Gómez, F., Moreira, D., and López-García, P. (2010). Molecular phylogeny of noctilucoid 476 dinoflagellates (Noctilucales, Dinophyceae). Protist 161(3), 466-478. 
478 Gozlan, R. E., Marshall, W., Lilje, O., Jessop, C., Gleason, F. H., and Andreou, D. (2014).

479 Current ecological understanding of fungal-like pathogens of fish: what lies beneath?

$480 \quad$ Frontiers in microbiology, 5, 62.

481

482 Guillou, L., Viprey, M., Chambouvet, A., Welsh, R.M., Kirkham, A.R., Massana, R., 483 Scanlan, D.J. and Worden, A.Z. (2008). Widespread occurrence and genetic diversity of 484 marine parasitoids belonging to Syndiniales (Alveolata). Environmental Microbiology, 485 10(12), 3349-3365.

486

487 Harada, A., Ohtsuka, S., and Horiguchi, T. (2007). Species of the parasitic genus

488 Duboscquella are members of the enigmatic Marine Alveolate Group I. Protist 158(3), $489 \quad 337-347$.

490

491 Harvell, C.D., Kim, K., Burkholder, J.M., Colwell, R.R., Epstein, P.R., Grimes, D.J., 492 Hofmann, E.E., Lipp, E.K., Osterhaus, A.D.M.E., Overstreet, R.M. and Porter, J.W. 493 (1999). Emerging marine diseases--climate links and anthropogenic factors. Science $494 \quad 285(5433), 1505-1510$.

495

496 Harvell, C. D., Mitchell, C. E., Ward, J. R., Altizer, S., Dobson, A. P., Ostfeld, R. S., and 497 Samuel, M. D. (2002). Climate warming and disease risks for terrestrial and marine biota. $498 \quad$ Science 296(5576), 2158-2162.

499

500 Hollande, A. and Cachon, J. (1952). Un parasite des oeufs de sardine: l'Ichthyodinium 501 chabelardi, nov. gen., nov. sp. CR Acad. Sci., Paris (Ser. D) 235, 976-977. 
503 Hollande, A. and Cachon, J. (1953). Morphologie et évolution d'un Péridinien parasite des 504 oeufs de sardine (Ichthyodinium chabelardi). Sta. Aquat. Pêches Ceutaglione 4, 321-331.

506 Ishimaru, K., Iida, N., Okada, T., and Miyashita, S. (2012). Ichthyodinium infection in the 507 embryos and yolk sac larvae of Pacific bluefin tuna Thunnus orientalis. Fish Pathology, 508 47(4), 143-146.

509

510 Jung, J. H., Choi, J. M., Coats, D. W., and Kim, Y. O. (2016). Euduboscquella costata n. 511 sp.(Dinoflagellata, Syndinea), an intracellular parasite of the ciliate Schmidingerella 512 arcuata: morphology, molecular phylogeny, life cycle, prevalence, and infection intensity. 513 Journal of Eukaryotic Microbiology 63(1), 3-15.

515 Kuperman, B. I., and Matey, V. E. (1999). Massive infestation by Amyloodinium 516 ocellatum (Dinoflagellida) of fish in a highly saline lake, Salton Sea, California, USA.

517 Diseases of Aquatic Organisms 39(1), 65-73.

519 Landsberg, J. H., Steidinger, K. A., Blakesley, B. A., and Zondervan, R. L. (1994).

520 Scanning electron microscope study of dinospores of Amyloodinium cf. ocellatum, a

521 pathogenic dinoflagellate parasite of marine fish, and comments on its relationship to the 522 Peridiniales. Diseases of Aquatic Organisms 20, 23-32.

524 Lessard, E. J., and Swift, E. (1986). Dinoflagellates from the North Atlantic classified as 525 phototrophic or heterotrophic by epifluorescence microscopy. Journal of Plankton 526 Research 8(6), 1209-1215. 
528 Levy, M. G., Poore, M. F., Colorni, A., Noga, E. J., Vandersea, M. W., and Litaker, R. W.

529 (2007). A highly specific PCR assay for detecting the fish ectoparasite Amyloodinium

530 ocellatum. Diseases of aquatic organisms 73(3), 219-226.

531

532 Lima-Mendez, G., Faust, K., Henry, N., Decelle, J., Colin, S., Carcillo, F., Chaffron, S.,

533 Ignacio-Espinosa, J.C., Roux, S., Vincent, F. and Bittner, L. (2015). Determinants of

534 community structure in the global plankton interactome. Science 348(6237), 1262073.

535

536 Loeblich, A. R. (1976). Dinoflagellate evolution: speculation and evidence. Journal of

537 Eukaryotic Microbiology 23(1), 13-28.

538

539 Lowe, C. D., Keeling, P. J., Martin, L. E., Slamovits, C. H., Watts, P. C., and Montagnes,

540 D. J. (2010). Who is Oxyrrhis marina? Morphological and phylogenetic studies on an

541 unusual dinoflagellate. Journal of Plankton Research 33(4), 555-567.

542

543 Meneses, I., Vendrell, C., and Stratoudakis, Y. (2003). Mackerel (Scomber scombrus)

544 eggs parasitized by Ichthyodinium chabelardi in the north-east Atlantic: an overlooked

545 source of mortality. Journal of plankton research 25(9), 1177-1181.

546 
547 Miller, J. J., Delwiche, C. F., and Coats, D. W. (2012). Ultrastructure of Amoebophrya sp. 548 and its changes during the course of infection. Protist 163(5), 720-745.

550 Moon-van der Staay, S. Y., De Wachter, R., and Vaulot, D. (2001). Oceanic 18S rDNA 551 sequences from picoplankton reveal unsuspected eukaryotic diversity. Nature 409(6820), 552607.

554 Mori, K.I., Yamamoto, K., Teruya, K., Shiozawa, S., Yoseda, K., Sugaya, T., Shirakashi, 555 S., Itoh, N. and Ogawa, K. (2007). Endoparasitic dinoflagellate of the genus 556 Ichthyodinium infecting fertilized eggs and hatched larvae observed in the seed production 557 of leopard coral grouper Plectropomus leopardus. Fish Pathology 42(1), 49-57.

559 Noga, E. J. (1989). Culture conditions affecting the in vitro propagation of Amyloodinium 560 ocellatum. Diseases of Aquatic Organisms 6(2), 137-143.

561

562 Norén, F., Moestrup, Ø., and Rehnstam-Holm, A. S. (1999). Parvilucifera infectans

563 Norén et Moestrup gen. et sp. nov.(Perkinsozoa phylum nov.): a parasitic flagellate 564 capable of killing toxic microalgae. European journal of protistology 35(3), 233-254.

566 Pascher, A. (1914). Uber flagellaten und algen. Deutsche Botanische Gesellschaft, 567 Berichte 32, 136-160. 
569 Pedersen, B. H., and Køie, M. (1994). A protistan endoparasite in embryos and yolk-sac 570 larvae of cod Gadus morhua and turbot Scophthalmus maximus. Diseases of Aquatic

571 Organisms 19, 39-46.

573 Phillips, A. J., Anderson, V. L., Robertson, E. J., Secombes, C. J., and Van West, P. 574 (2008). New insights into animal pathogenic oomycetes. Trends in microbiology 16(1), 575 13-19.

576

577 Robledo, J. A. F., Caler, E., Matsuzaki, M., Keeling, P. J., Shanmugam, D., Roos, D. S., 578 and Vasta, G. R. (2011). The search for the missing link: a relic plastid in Perkinsus?. 579 International journal for parasitology 41(12), 1217-1229.

581 Rowley, J. J., Gleason, F. H., Andreou, D., Marshall, W. L., Lilje, O., and Gozlan, R. 582 (2013). Impacts of mesomycetozoean parasites on amphibian and freshwater fish 583 populations. Fungal Biology Reviews 27(3-4), 100-111.

585 Sarowar, M. N., Saraiva, M., Jessop, C. N., Lilje, O. Gleason, F. H. and van West, P. 586 (2014). Infection strategies of pathogenic oomycetes in fish. In: 'Freshwater fungi and 587 fungus-like organisms.' (Eds E. B. G. Jones, K-L. Pang, L. D. Hyde.) pp. 217-244. De 588 Gruyter: Berlin, Germany.

590 Shadrin, A. M., Kholodova, M. V., and D. S. Pavlov. 2010a. Geographical distribution 591 and molecular genetic identification of the parasite of the genus Ichthyodinidium causing 
595 Shadrin, A. M., Pavlov, D. S., and Kholodova, M. V. (2010b). Long-term dynamics of 596 infection of fish eggs and larvae with the endoparasite Ichthyodinium sp. (Dinoflagellata) 597 in Nha Trang Bay, Vietnam. Fish Pathology 45, 103-108.

599 Shadrin, A. M., Simdyanov, T. G., Pavlov, D. S., and Nguyen, T. H. T. (2015). Free600 living stages of the life cycle of the parasitic dinoflagellate Ichthyodinium chabelardi 601 Hollande et J. Cachon, 1952 (Alveolata: Dinoflagellata). Doklady Biological Sciences 602 461(1), 104-107.

603

604 Shields, J. D. (1994). The parasitic dinoflagellates of marine crustaceans. Annual Review 605 of Fish Diseases 4, 241-271.

606

607 Simdyanov, T. G., Shadrin, A. M., and Thanh, N. T. H. (2016). The ultrastructure of the 608 zoospores of the parasitic dinoflagellate Ichthyodinium chabelardi Hollande et J. Cachon, 6091952 (Alveolata: Dinoflagellata). Doklady Biological Sciences 468(1), 125-128.

611 Skovgaard, A., Meneses, I., and Angélico, M. M. (2009). Identifying the lethal fish egg

612 parasite Ichthyodinium chabelardi as a member of Marine Alveolate Group I.

613 Environmental microbiology 11(8), 2030-2041. 
615 Skovgaard, A., Meyer, S., Overton, J. L., Støttrup, J., and Buchmann, K. (2010).

616 Ribosomal RNA gene sequences confirm that protistan endoparasite of larval cod Gadus

617 morhua is Ichthyodinium sp. Diseases of aquatic organisms, 88(2), 161-167.

619 Small, H. J., and Pagenkopp, K. M. (2011). Reservoirs and alternate hosts for pathogens

620 of commercially important crustaceans: a review. Journal of invertebrate pathology

621 106(1), 153-164.

623 Small, H. J., Shields, J. D., Reece, K. S., Bateman, K., and Stentiford, G. D. (2012).

624 Morphological and molecular characterization of Hematodinium perezi (Dinophyceae:

625 Syndiniales), a dinoflagellate parasite of the harbour crab, Liocarcinus depurator. Journal 626 of Eukaryotic Microbiology 59(1), 54-66.

628 Sørensen, S. R., Tomkiewicz, J., and Skovgaard, A. (2014). Ichthyodinium identified in

629 the eggs of European eel (Anguilla anguilla) spawned in captivity. Aquaculture 426, $197-$ 630203.

631

632 Stentiford, G. D., and Shields, J. D. (2005). A review of the parasitic dinoflagellates

633 Hematodinium species and Hematodinium-like infections in marine crustaceans. Diseases 634 of aquatic organisms 66(1), 47-70. 
636 Stentiford, G.D., Neil, D.M., Peeler, E.J., Shields, J.D., Small, H.J., Flegel, T.W., Vlak, 637 J.M., Jones, B., Morado, F., Moss, S. and Lotz, J. (2012). Disease will limit future food 638 supply from the global crustacean fishery and aquaculture sectors. Journal of invertebrate 639 pathology 110(2), 141-157.

640

641 Stratoudakis, Y., Barbosa, A., and Meneses, I. (2000). Infection of sardine eggs by the

642 protistan endoparasite Ichthyodinium chabelardi off Portugal. Journal of fish biology

$643 \quad 57(2), 476-482$.

644

645 Sutherst, R. W. (2001). The vulnerability of animal and human health to parasites under 646 global change. International journal for parasitology 31(9), 933-948.

648 Taylor, F. J. R. (1968). Parasitism of the toxin-producing dinoflagellate Gonyaulax

649 catenella by the endoparasitic dinoflagellate Amoebophrya ceratii. Journal of the

650 Fisheries Board of Canada 25(10), 2241-2245.

651

652 Thoen, E., Vrålstad, T., Rolén, E., Kristensen, R., Evensen, Ø., and Skaar, I. (2015).

653 Saprolegnia species in Norwegian salmon hatcheries: field survey identifies S. diclina

654 sub-clade IIIB as the dominating taxon. Diseases of aquatic organisms 114(3), 189-198.

655

656 Van West, P. (2006). Saprolegnia parasitica, an oomycete pathogen with a fishy appetite:

657 new challenges for an old problem. Mycologist 20(3), 99-104. 
659 Yuasa, K., Kamaishi, T., Mori, K. I., Hutapea, J. H., Permana, G. N., and Nakazawa, A. 660 (2007). Infection by a protozoan endoparasite of the genus Ichthyodinium in embryos and 661 yolk-sac larvae of yellowfin tuna Thunnus albacares. Fish Pathology 42(1), 59-66.

662

663

664

665 